\title{
Occupational Allergic Diseases in Kitchen and Health Care Workers: An Underestimated Health Issue
}

\author{
Ugur Bilge, ${ }^{1}$ Ilhami Unluoglu, ${ }^{1}$ Nazan Son, ${ }^{1}$ Ahmet Keskin, ${ }^{2}$ \\ Yasemin Korkut, ${ }^{3}$ and Murat Unalacak ${ }^{1}$ \\ ${ }^{1}$ Department of Family Medicine, Faculty of Medicine, Eskisehir Osmangazi University, 9026480 Eskisehir, Turkey \\ ${ }^{2}$ Ankara Cankaya 4th Primary Care, 9006100 Ankara, Turkey \\ ${ }^{3}$ Department of Family Medicine, Faculty of Medicine, Dumlupinar University, 9043100 Kutahya, Turkey
}

Correspondence should be addressed to Ugur Bilge; dr_ubilge@windowslive.com

Received 22 August 2013; Revised 14 October 2013; Accepted 14 October 2013

Academic Editor: Ralph Mösges

Copyright (C) 2013 Ugur Bilge et al. This is an open access article distributed under the Creative Commons Attribution License, which permits unrestricted use, distribution, and reproduction in any medium, provided the original work is properly cited.

Objective. This study evaluated the frequencies of allergic symptoms and rate of upper respiratory infections during the past year in the general population, kitchen workers (KW) and health care workers (HCW). Methods. The European Community Respiratory Health Survey (ECRHS) was used to inquire retrospectively about asthma and asthma-like symptoms and the number of treatments required for previous upper respiratory tract infections (URTI: acute pharyngitis, acute sinusitis, etc.) during the past year for health care workers, kitchen workers, and members of the general population. Adjusted odds ratios by gender, age, and smoking status were calculated. Results. 579 subjects ( 186 from the general population, $205 \mathrm{KW}$, and $188 \mathrm{HCW} ; 263$ females, 316 males) participated in the study. Noninfectious (allergic) rhinitis was significantly higher in the HCW and KW groups than in the general population $(P<0.001)$. Cumulative asthma was significantly higher only in the HCW group $(P<0.05)$. In addition, the HCW and KW groups had significantly higher risks of $\geq 2$ /year URTI (OR: 1.59, 95\% CI: 1.07-2.38 versus OR: 1.57, 95\% CI: 1.05-2.38) than the general population. Conclusion. Occupational allergic respiratory diseases are an important and growing health issue. Health care providers should become familiar with workplace environments and environmental causes of occupational rhinitis and asthma.

\section{Introduction}

Allergic diseases are common and important health problems, as their prevalence is increasing worldwide. Allergic diseases also constitute an economic burden, as they affect quality of life and work life $[1,2]$.

Two major factors that can trigger the development and severity of allergic disease are host factors and environmental factors [3]. Environmental stimulants, including indoor allergens, can affect the development of allergic responses [3]. Indoor allergens involved in this process can include arthropod allergens, mammalian allergens, fungal allergens, and also occupational allergens [3-6]. Occupational asthma and allergic rhinitis are common respiratory diseases in industrialized countries [7]. Occupational allergic diseases can affect workers' productivity and quality of life [8]. Many occupations are at risk of allergic diseases such as occupational asthma and allergic rhinitis. These occupational groups include health care staff, kitchen workers, spray painters, bakers, laboratory technicians, and hairdressers $[9,10]$. About 250 agents have been identified as causes of occupational allergic diseases [11].

According to studies on kitchen workers, there has been an increase in respiratory diseases like asthma, allergic rhinitiss and emphysema that may be associated with exposure to cooking fumes, disinfectants, cockroaches, and mice $[3,5]$. During food preparation under high temperatures, harmful products like fat aerosols and aldehydes can be formed, which can cause respiratory symptoms [5].

Data on health care workers shows that an increased risk of allergic diseases and occupational allergy has become an important health problem [12]. Potential allergens for this group are latex, disinfectants, sterilants, pharmaceuticals, sensitizing metals, methacrylates, irritant aerosolized medications, and cleaning products [13-15]. Although occupational allergic diseases affect productivity and workers' health, their effects are usually underestimated. 
In this study, we aimed to evaluate the frequencies of allergic symptoms, cigarette smoking, and upper respiratory tract infections (URTI) during the past year in the general population, kitchen workers, and health care workers.

\section{Materials and Methods}

This was an observational, cross-sectional study. A total of 579 subjects over the age of 18 participated. The subjects were recruited from kitchen workers (KW), health care workers (HCW) (doctors, nurses, and paramedics), and the general population. All data were collected in Eskisehir and Kutahya, which are in the northwestern part of Central Anatolia in Turkey. The socioeconomic levels of these cities were judged as average for Turkey. The participants were informed about the purpose of the study and voluntarily took part. A of total 250 HCW were approached, but only 188 of them agreed to participate. The kitchen workers were selected from three university kitchens (two in Eskisehir, one in Kutahya), which have 205 workers in total. All KW agreed to participate. To evaluate occupational effects on allergic symptoms and URTI, subjects who had worked for at least one year in the same job were included in the study. Kitchen workers' data were collected from three different kitchens, and health workers' data were collected from three different hospitals. The general population data were collected in the centers of the two cities. These subjects were selected by a simple random sampling method. A two-stage questionnaire was administered to people who volunteered to participate. In the first stage of the questionnaire, sociodemographic characteristics and smoking behavior of the participant were recorded; the number of upper respiratory tract infections (acute pharyngitis, acute sinusitis, etc.) that required treatment during the previous year was reported retrospectively. In the second stage of the questionnaire, the European Community Respiratory Health Survey (ECRHS) was administered to inquire about asthma and asthma-like symptoms. A chisquare test was used to examine the extent of relationships through a univariate analysis of the data obtained from the questionnaire. A logistic regression model was used for the multivariate analyses. Three main groups were included in the study, and the study design can be represented by a $2 \times 3$ contingency table. A power analysis was performed on this table using a chi-square test. Alpha was set at 0.05 and beta at 0.20 , so the power was equal to 0.80 and the sample size of 571 was calculated to be enough for the $80 \%$ level of power. The categorical variables for all three groups were determined, and then adjusted odds ratios by gender, age, and smoking status (OR) for 95\% confidence intervals (95\% CI) were calculated. The median number of URTIs per year was 2, and ORs were calculated for all groups as 0 -1/year and $\geq 2$ /year. All statistical analyses were performed using SPSS 16.0 for Windows.

\section{Results}

A total of 579 subjects (186 from the general population, 205 KW and 188 HCW; 263 females, 316 males) were included in the study. Mean age \pm standard deviation was $36.17 \pm 10.65$ years. Mean age \pm standard deviations of the groups were $39.59 \pm 14.80$ years for the general population, $35.90 \pm 7.12$ for the kitchen workers, and $33.07 \pm 7.56$ for the health care workers. When comparisons between the general population and groups were made, noninfectious (allergic) rhinitis was significantly higher in the HCW and KW groups $(P<0.001)$. Cumulative asthma was significantly higher only in the HCW group $(P<0.05)$. Results of the questionnaire according to groups are presented in Table 1 . When adjusted odds ratios by gender, age, and smoking status were calculated, being a HCW or a KW produced a 1.97-fold risk (OR: 1.97, 95\% confidence interval (CI): 1.28-3.04) and 1.931fold risk (OR: 1.85, 95\% CI: 1.26-2.95) for noninfectious rhinitis, respectively. We did not observe any other significant relationships between groups. We also evaluated the URTI risk in the three groups and found that in the HCW and KW groups there were significantly higher risks of $\geq 2$ /year URTI (OR: 1.59, 95\% CI: $1.07-2.38$ versus OR: 1.57, 95\% CI: $1.05-$ 2.38) in comparison with the general population. However when adjusted odds ratios were calculated, we found that in the HCW group there is a significantly higher risk of $\geq 2 /$ year URTI (OR: 1.56, 95\% CI: 1.01-2.40). Average working years for groups, with standard deviations, were found to be $10.70 \pm$ 7.51 years for HCW and $12.36 \pm 7.07$ years for KW. We calculated the median working years for both of the workers' groups and found that working in a kitchen more than 12 years was related to a 2.30 -fold risk of asthma-like symptoms (37.4\% versus $57.9 \%$, OR: 2.30 , 95\% CI: $1.31-4.05$ ), compared to workers who had worked equal or less than 12 years. Two hundred fifteen of the subjects who participated in the study $(33.9 \%)$ were regular smokers. When we evaluated the relationship between allergic diseases and allergic symptoms, we found a 4.193-fold risk of asthma-like symptoms (OR: 4.193, 95\% CI: 2.93-6.00) in smokers, which was significant $(P<0.05)$.

\section{Discussion}

As $15 \%$ of adult asthma is attributed to the workplace environment, occupational respiratory diseases, especially asthma and allergic rhinitis, can be prevented through appropriate protective strategies. Allergic respiratory diseases can be caused by many allergens: aldehydes, flour, isocyanates, latex, persulphate, salts, disinfectants, sterilants, antibiotics, and cooking fumes, mostly seen in kitchen workers, health care workers, hairdressers, and cleaners [16-18]. According to studies on $\mathrm{KW}$, food particle inhalation, cockroaches, and mice can cause respiratory symptoms such as nasal symptoms (rhinorrhea, sneezing, nasal congestion), lower respiratory and symptoms (cough, wheeze) and, rarely, anaphylaxis. Rhinitis can occur before occupational asthma, and rhinoconjunctivitis is also related to this condition [19]. In our data, asthma-like symptoms were significantly higher in the subjects who had worked for more than 12 years in kitchens, which can be harbingers of occupational asthma. In addition, kitchen workers have higher risk factors for lung cancer and emphysema [20-22]. Interestingly, we found that 
TABLE 1: Distributions of allergic symptoms according to groups.

\begin{tabular}{|c|c|c|c|c|}
\hline $\begin{array}{l}\text { European Community } \\
\text { Respiratory Health Survey } \\
\text { (ECRHS) questionnaire }\end{array}$ & $\begin{array}{l}\text { Questionnaire } \\
\text { diagnoses }\end{array}$ & $\begin{array}{l}\text { General population } \\
(n / N)(\%)\end{array}$ & $\begin{array}{l}\text { Kitchen workers } \\
\quad(n / N)(\%)\end{array}$ & $\begin{array}{c}\text { Health care } \\
\text { workers }(n / N)(\%)\end{array}$ \\
\hline $\begin{array}{l}\text { Saying "Yes" to Q1 and/or Q2 } \\
\text { and/or Q3 and/or Q4 }\end{array}$ & $\begin{array}{l}\text { With asthma-like } \\
\text { symptoms }\end{array}$ & $\begin{array}{c}(77 / 186) \\
41.4\end{array}$ & $\begin{array}{c}100 / 205 \\
48.8\end{array}$ & $\begin{array}{c}70 / 188 \\
37.2\end{array}$ \\
\hline $\begin{array}{l}\text { Current asthma: saying "Yes" to } \\
\text { Q5 and Q7 }\end{array}$ & With current asthma & $\begin{array}{c}(11 / 186) \\
5.9\end{array}$ & $\begin{array}{c}6 / 205 \\
2.9\end{array}$ & $\begin{array}{c}10 / 188 \\
5.7\end{array}$ \\
\hline $\begin{array}{l}\text { Cumulative asthma: saying "Yes" } \\
\text { to Q6 }\end{array}$ & $\begin{array}{l}\text { With cumulative } \\
\text { asthma }\end{array}$ & $\begin{array}{c}(11 / 186) \\
5.9\end{array}$ & $\begin{array}{c}5 / 205 \\
2.4\end{array}$ & $\begin{array}{c}19 / 188 \\
10.1^{*}\end{array}$ \\
\hline $\begin{array}{l}\text { Noninfectious (allergic) rhinitis: } \\
\text { saying “Yes" to Q8 }\end{array}$ & $\begin{array}{l}\text { With noninfectious } \\
\text { rhinitis }\end{array}$ & $\begin{array}{c}(70 / 186) \\
37.6\end{array}$ & $\begin{array}{c}108 / 205^{* *} \\
52.7\end{array}$ & $\begin{array}{c}107 / 188^{* *} \\
56.9\end{array}$ \\
\hline $\begin{array}{l}\text { Pruritic dermatitis and/or } \\
\text { eczema: saying "Yes" to Q9 }\end{array}$ & $\begin{array}{l}\text { With pruritic } \\
\text { dermatitis and/or } \\
\text { eczema }\end{array}$ & $\begin{array}{c}(51 / 186) \\
27.4\end{array}$ & $\begin{array}{c}61 / 205 \\
29.8\end{array}$ & $\begin{array}{c}58 / 188 \\
30.9\end{array}$ \\
\hline
\end{tabular}

${ }^{*} P<0.05,{ }^{* *} P<0.001$.

the cumulative asthma rate was lower than it was in the general population. The reason for such a finding may be that the workers with allergic symptoms had to change their jobs due to their occupational allergic symptoms or they did not seek work in such jobs. A study with bakers found that allergic symptoms can be the reason for changing jobs [23].

Health care workers have an increased risk of occupational allergic diseases since they were medical students. They have increased risks of contact dermatitis, allergic rhinitis, sinusitis, and bronchial asthma [24, 25]. Such diseases are caused by occupational allergens such as drugs, pollens, disinfectants, and hand cleaning substances. In our findings, being a HCW or KW was associated with an increased odds ratio of having noninfectious rhinitis. Occupational rhinitis is a health problem that receives less attention than occupational asthma [26]. It is an inflammatory disease characterized by intermittent or persistent symptoms, and it can be caused by particular working environments or exacerbated by occupational exposure.

We found that being a $\mathrm{KW}$ or a $\mathrm{HCW}$ was associated with increased odds of having URTI. Chemical solvents, latex, antibiotics, and cooking oils are the major contributors to respiratory symptoms, and they can cause both allergic symptoms and upper respiratory tract infections [12, 27]. Also well, the presence of allergic symptoms is considered to be a risk factor for upper respiratory tract infections $[28,29]$.

The economic importance of work-related allergic diseases is growing, as they cause an increase in airway diseases like asthma, disease-related productivity loss, and a decrease in quality of life. Further, the medications used for treatment can cause adverse effects [30-34]. Prevention of occupational allergic diseases should be important for all healthcare providers. Controlling exposure in the workplace, identification of susceptible workers, and secondary prevention are the main means of prevention [26]. Secondary prevention includes periodical investigations of occupational allergic symptoms, early referral of symptomatic workers, and identification of workers who have possible asthma as well as occupational allergic diseases [26].

\section{Conclusions}

Occupational allergic respiratory diseases are an important health issue and their importance is growing. Health care providers should become familiar with the workplace environment and environmental causes of occupational rhinitis and asthma. Although giving appropriate medications is important, all health care providers should also encourage changes in the working environment to protect the workers' health. Paying attention to the working environment can result in decreases in occupational asthma and in progressive respiratory deterioration [35].

\section{References}

[1] B. Leynaert, C. Neukirch, R. Liard, J. Bousquet, and F. Neukirch, "Quality of life in allergic rhinitis and asthma: a populationbased study of young adults," The American Journal of Respiratory and Critical Care Medicine, vol. 162, no. 4, part 1, pp. 13911396, 2000.

[2] J. Bousquet, P. van Cauwenberge, and N. Khaltaev, "Allergic rhinitis and its impact on asthma," Journal of Allergy and Clinical Immunology, vol. 108, no. 5, supplemet, pp. S147-S334, 2001.

[3] D. Peden and C. E. Reed, "Environmental and occupational allergies," Journal of Allergy and Clinical Immunology, vol. 125, no. 2, supplement 2, pp. S150-S160, 2010.

[4] G. Moscato, P. Pignatti, M.-R. Yacoub, C. Romano, S. Spezia, and L. Perfetti, "Occupational asthma and occupational rhinitis in hairdressers," Chest, vol. 128, no. 5, pp. 3590-3598, 2005.

[5] K. Svendsen, A. K. Sjaastad, and I. Sivertsen, "Respiratory symptoms in kitchen workers," The American Journal of Industrial Medicine, vol. 43, no. 4, pp. 436-439, 2003.

[6] P. I. Ruoppi, T. M. Husman, M. H. Reiman, J. Nuutinen, A. M. Hyvärinen, and A. I. Nevalainen, "Nasal symptoms among residents in moldy housing," Scandinavian Journal of Work, Environment and Health, vol. 29, no. 6, pp. 461-467, 2003.

[7] J.-P. Zock, M. Kogevinas, J. Sunyer et al., "Asthma risk, cleaning activities and use of specific cleaning products among Spanish indoor cleaners," Scandinavian Journal of Work, Environment and Health, vol. 27, no. 1, pp. 76-81, 2001. 
[8] T. S. Higgins and D. D. Reh, "Environmental pollutants and allergic rhinitis," Current Opinion in Otolaryngology \& Head and Neck Surgery, vol. 20, no. 3, pp. 209-214, 2012.

[9] K. M. Venables and M. Chan-Yeung, "Occupational asthma," The Lancet, vol. 349, no. 9063, pp. 1465-1469, 1997.

[10] S. Meredith, "Reported incidence of occupational asthma in the United Kingdom, 1989-90," Journal of Epidemiology and Community Health, vol. 47, no. 6, pp. 459-463, 1993.

[11] M. Chan-Yeung and J.-L. Malo, "Aetiological agents in occupational asthma," European Respiratory Journal, vol. 7, no. 2, pp. 346-371, 1994.

[12] K. Sato, Y. Kusaka, N. Suganuma, S. Nagasawa, and Y. Deguchi, "Occupational allergy in medical doctors," Journal of Occupational Health, vol. 46, no. 2, pp. 165-170, 2004.

[13] G. L. Delclos, D. Gimeno, A. A. Arif et al., "Occupational risk factors and asthma among health care professionals," The American Journal of Respiratory and Critical Care Medicine, vol. 175, no. 7, pp. 667-675, 2007.

[14] C. E. Mapp, P. Boschetto, P. Maestrelli, and L. M. Fabbri, "Occupational asthma," The American Journal of Respiratory and Critical Care Medicine, vol. 172, no. 3, pp. 280-305, 2005.

[15] E. Pechter, L. K. Davis, C. Tumpowsky et al., "Work-related asthma among health care workers: surveillance data from California, Massachusetts, Michigan, and New Jersey, 19931997," The American Journal of Industrial Medicine, vol. 47, no. 3, pp. 265-275, 2005.

[16] J. Ameille, A. Larbanois, A. Descatha, and O. Vandenplas, "Epidemiology and aetiological agents of occupational asthma," Revue des Maladies Respiratoires, vol. 23, no. 6, pp. 726-740, 2006.

[17] D. A. Ramirez Jr and S. L. Bahna, "Food hypersensitivity by inhalation," Clinical and Molecular Allergy, vol. 7, article 4, 2009.

[18] S. Meredith and H. Nordman, "Occupational asthma: measures of frequency from four countries," Thorax, vol. 51, no. 4, pp. 435440, 1996.

[19] J.-L. Malo, C. Lemière, A. Desjardins, and A. Cartier, "Prevalence and intensity of rhinoconjunctivitis in subjects with occupational asthma," European Respiratory Journal, vol. 10, no. 7, pp. 1513-1515, 1997.

[20] D. Coggon, B. Pannett, C. Osmond, and E. D. Acheson, "A survey of cancer and occupation in young and middle aged men. I. Cancers of the respiratory tract," British Journal of Industrial Medicine, vol. 43, no. 5, pp. 332-338, 1986.

[21] E. Lund, Kokker og dødelighet av kreft. (Cancer and mortality in cooks) Rapport fra Direktoratet for Arbeidstilsynet, Direktoratet for Arbeidstilsynet, Oslo, Norway, 1986.

[22] J. Borgan and L. Kristoffersen, DødelIghet I Yrker Og sosIoøkonomIskegrupper 1970-1980. (Mortality By occupatIon and socIoeconomIc Group In Norway 1970-1980) Norsk statIstIkk, Statistisk Sentralbyrå, Oslo, Norway, 1986.

[23] T. Storaas, S. K. Steinsvåg, E. Florvaag, A. Irgens, and T. B. Aasen, "Occupational rhinitis: diagnostic criteria, relation to lower airway symptoms and IgE sensitization in bakery workers," Acta Oto-Laryngologica, vol. 125, no. 11, pp. 1211-1217, 2005.

[24] K. Sato, Y. Kusaka, Q. Zhang et al., "An epidemiological study of the mercury sensitization," Allergology International, vol. 46, pp. 201-206, 1997.

[25] V. Nagendran, J. Wicking, A. Ekbote, T. Onyekwe, and L. H. Garvey, "IgE-mediated chlorhexidine allergy: a new occupational hazard?" Occupational Medicine, vol. 59, no. 4, pp. 270$272,2009$.
[26] G. Moscato, O. Vandenplas, R. G. van Wijk, J. L. Malo, L. Perfetti, S. Quirce et al., "EAACI position paper on occupational rhinitis," Respiratory Research, vol. 10, article 16, 2009.

[27] T. D. LeVan, W.-P. Koh, H.-P. Lee, D. Koh, M. C. Yu, and S. J. London, "Vapor, dust, and smoke exposure in relation to adultonset asthma and chronic respiratory symptoms: the Singapore Chinese health study," The American Journal of Epidemiology, vol. 163, no. 12, pp. 1118-1128, 2006.

[28] J. A. Sacre Hazouri, "Allergic rhinitis. Coexistent diseases and complications. A review and analysis," Revista Alergia México, vol. 53, no. 1, pp. 9-29, 2006.

[29] K. J. Kværner, K. Tambs, J. R. Harris, I. W. S. Mair, and P. Magnus, "Otitis media: relationship to tonsillitis, sinusitis and atopic diseases," International Journal of Pediatric Otorhinolaryngology, vol. 35, no. 2, pp. 127-141, 1996.

[30] B. P. Yawn, J. W. Yunginger, P. C. Wollan, C. E. Reed, M. D. Silverstein, and A. G. Harris, "Allergic rhinitis in Rochester, Minnesota residents with asthma: frequency and impact on health care charges," Journal of Allergy and Clinical Immunology, vol. 103, no. 1 I, pp. 54-59, 1999.

[31] D. Price, Q. Zhang, V. S. Kocevar, D. D. Yin, and M. Thomas, "Effect of a concomitant diagnosis of allergic rhinitis on asthmarelated health care use by adults," Clinical and Experimental Allergy, vol. 35, no. 3, pp. 282-287, 2005.

[32] I. M. Cockburn, H. L. Bailit, E. R. Berndt, and S. N. Finkelstein, "Loss of work productivity due to illness and medical treatment," Journal of Occupational and Environmental Medicine, vol. 41, no. 11, pp. 948-953, 1999.

[33] L. P. Hanrahan and L. C. Paramore, "Aeroallergens, allergic rhinitis, and sedating antihistamines: risk factors for traumatic occupational injury and economic impact," The American Journal of Industrial Medicine, vol. 44, no. 4, pp. 438-446, 2003.

[34] G. C. M. Groenewoud, H. de Groot, and R. G. van Wijk, "Impact of occupational and inhalant allergy on rhinitis-specific quality of life in employees of bell pepper greenhouses in the Netherlands," Annals of Allergy, Asthma and Immunology, vol. 96, no. 1, pp. 92-97, 2006.

[35] R. G. Slavin, "The allergist and the workplace: occupational asthma and rhinitis," Allergy and Asthma Proceedings, vol. 26, no. 4, pp. 255-261, 2005. 


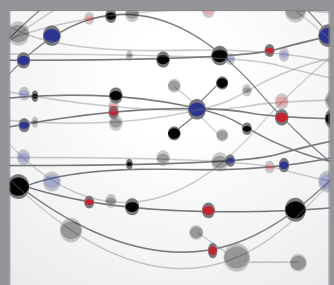

The Scientific World Journal
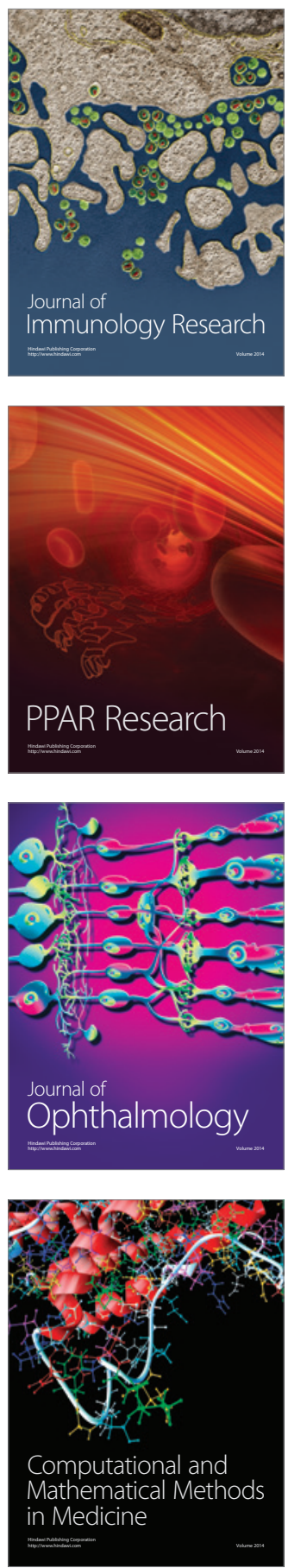

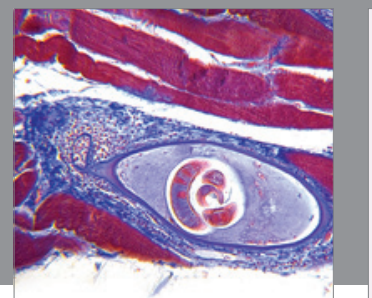

Gastroenterology

Research and Practice
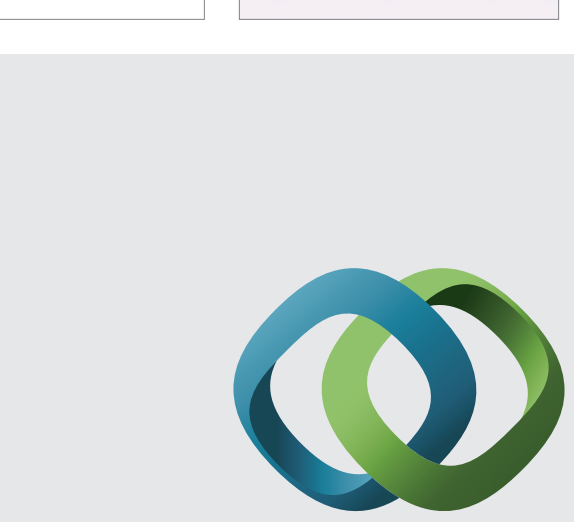

\section{Hindawi}

Submit your manuscripts at

http://www.hindawi.com
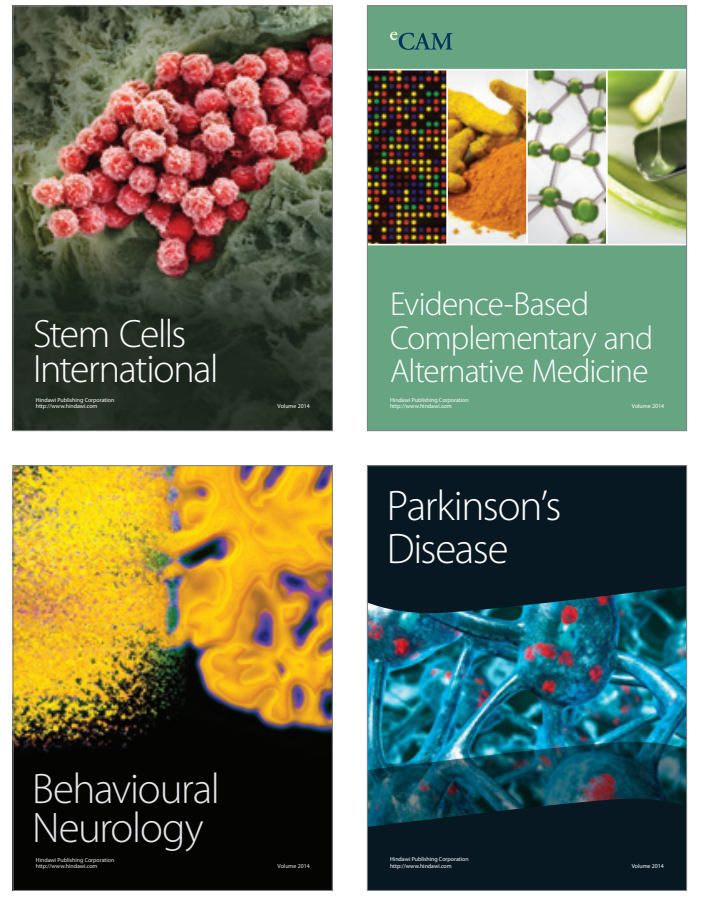
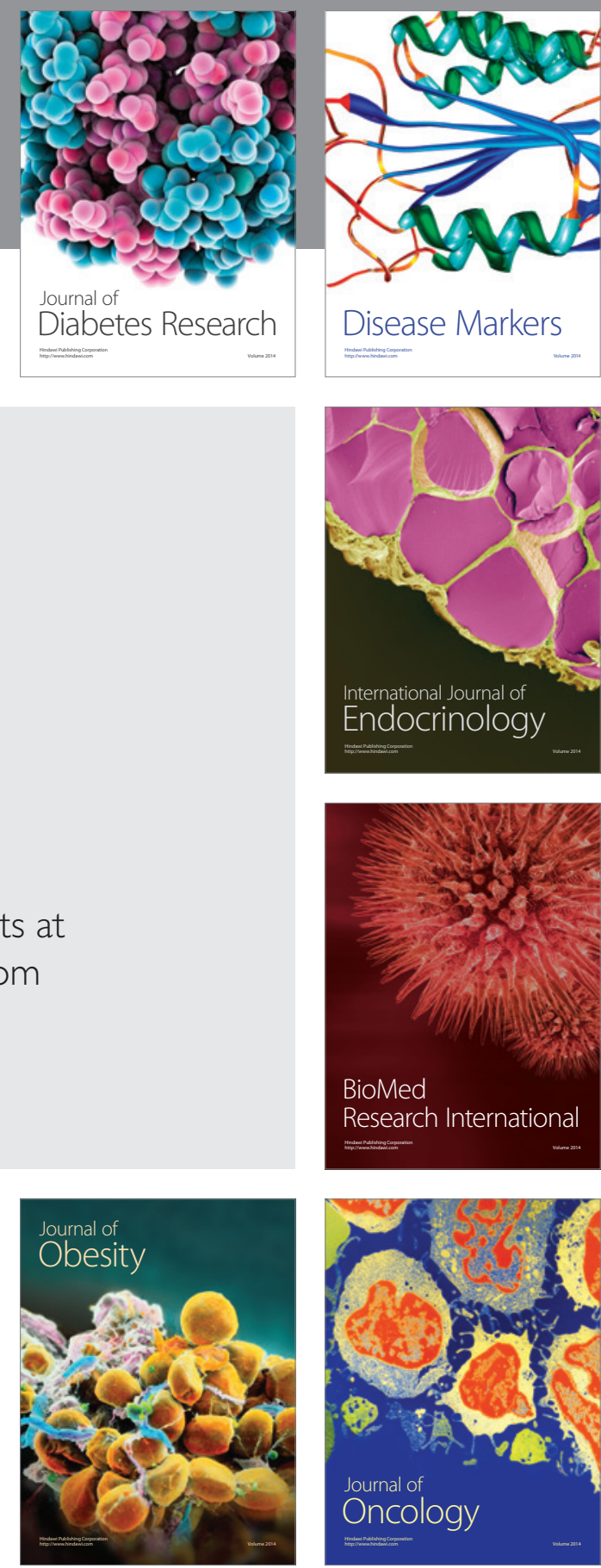

Disease Markers
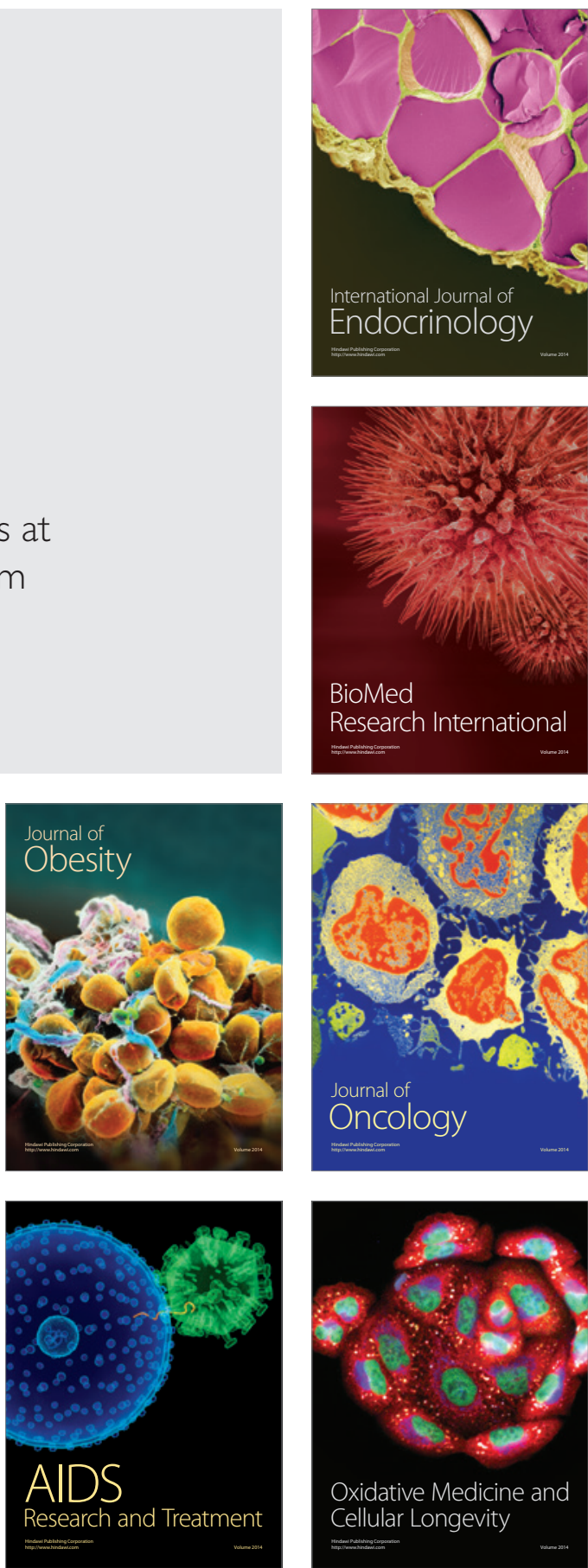